\title{
The Impact and Importance of Communication Within the Agricultural Units in Romania in the Digital Era
}

\author{
By Raluca-Elena Ghinea ${ }^{1}$, Alina Nicoleta Birsan ${ }^{2}$, Lorian Vintila ${ }^{3}$, Cristina State ${ }^{4}$
}

\begin{abstract}
The main objective of this paper is to analyse the degree of importance that the staff carrying out their activity within agricultural units in Romania gives to both internal and external organizational communication, and the impact, along with the implementations made, of the transition to the digital age. The research was quantitative, in the form of an online questionnaire, placed in a crowdsourcing system, distributed to the staff operating in agricultural units, holding both execution and management positions. It was filled in by 996 people, and the research started from the main idea that at local level, as well as institutional (ministry) level, there is still no concern for improving and enhancing professionalism and communication development, both externally as well as internally, in the context of the digital age we are experiencing. For an accuracy of the information, our analysis was based on 3 hypotheses. Testing the hypotheses based on obtained results led to the validation thereof and allowed us to draw up appropriate conclusions.
\end{abstract}

Keywords: organizational communication, digital age, agriculture, strategy

\section{Introduction}

According to Eurostat, in 2020, the agricultural sector contributed by around EUR 171.9 billion to the value of GDP in EU Member States, respectively, by an equivalent of $1.3 \%$ of the total. Industrialized agricultural products achieved a gross added value estimated around EUR 177 billion. The total value of agricultural production in 2020 was estimated at EUR 411.8 billion, of which about half $(52.8 \%)$ come from crops (including $14.0 \%$ from vegetables and $11.2 \%$ from cereals), and just under two-fifths (38.6\%) from animals and products of animal origin (including 13.1\% from milk and 9.6\% from pigs). The rest comes from agricultural services and inseparable non-agricultural activities. (available at: https://ec.europa.eu/eurostat/web/products-eurostat-news/$/$ ddn-20210413-2?redirect $=\% 2$ Feurostat $\% 2$ Fweb $\% 2$ Fagriculture $\% 2$ Fpublications, accessed 27.04.2021).

The agricultural sector plays an extremely important role in each country's economy. Therefore, agricultural units in the country are responsible for this economic branch's management and smooth running. Therefore, the management of the units must take into account a variety of aspects to obtain the efficiency thereof. One of these is communication, both at the intra-organizational level as well as the communication carried out with the stakeholders of the organizations.

Reality and practice have shown that there are major gaps in this area within the units. 
And, although it is more than necessary, no educational institution with an agricultural profile in the country includes in the university curriculum a study subject focused on communication. For this reason, but not exclusively, there are major deficiencies in internal and /or external communication within agricultural units, so that, over time, even their image is damaged.

Another important aspect is related to digitization; processes in general, communication in particular, needing adaptation and correlation with the progress that takes place in the economy. If communication policies and/or strategies are passed on from generation to generation, without being improved and adapted to the era of digitalization in which we live, the quality of the communication process decreases dramatically, especially in the process of organizational communication. In order to conclude previously presented information, according to experts (McNamara, 2020; Popescu et State, 2017), one principle for successful internal communication is to promote the transfer of information, as swiftly as possible, through nowadays digital means.

\section{Literature Review}

The communication process is extremely important and, equally, subjective; as Fiske (2010) states, communication is an activity recognized by every individual, but which very few manage to define properly. At the same time, communication is described by other authors as an action by which one source influences another, using alternative systems (Osgood, 1953). Some scholars consider communication to be a sum of the ways in which one can affect another individual (Shannon et Weaver, 1998), or, in a narrow sense, according to Schramm (1971), communication is the complex process by which a communion, an identity of reflections and conceptions can be established, through a communication channel, between a receiver and a sender. Generically, the communication process can be described as a complex one, of transmitting and receiving messages, by means of specific channels (State, 2015).

Communication is a particularly important aspect in conveying messages in a fair, clear and transparent manner. While between individuals, the communication process plays an extremely important role, the more valuable it is at the level of an organization. It cannot function in a harmonious way internally without an appropriate communication strategy and, moreover, it cannot transmit the intended message to the external environment without clearly defined communication policies. According to some specialists, organizational excellence can be defined as the ability of people to use technology in order to creatively solve complex problems (Zlate, 2004). Without communication, excellence cannot exist.

J.C. Abric (2002) was describing communication as a social act, intended or not intended, conscious or unconscious. According to another definition issued by experts (Nicolescu et Verboncu, 2007), communication is defined as a complex process of transmission of pieces of information, as symbolic messages, between two or more persons, holding the status of emitter, respectively receiver, through specific channels.

Communication is extremely important in any domain and agriculture is no exception to that. One study issued 6 years ago was describing the fact that, at the end of $2020,90 \%$ of global population, aged over 6 years old would have access to a mobile phone (Woods, 
2014). Therefore, this electronic device is playing an extremely important role, especially since agro-counselling over the phone services are increasingly appreciated, favouring a decrease of lack of information and an increase of technological progress awareness (Mittal, 2016). The phenomenon of E-agriculture will reduce knowledge gaps, stimulating the increase of efficiency (Petkovic, 2019), and mobile services will be able to prove themselves as a costs wise efficient apparatus for guiding farmers towards profitable agricultural practices (Cole \& Nilesh, 2016). Nevertheless, according to specialists from various countries, communication in the agricultural domain is being done both formally and informally (Treise \& Weigood, 2002), making reference to all domains connected to agricultural enterprises (Boone, Meisenbach \& Tucker, 2000).

\section{Research Methodology}

The first activities carried out in this research were those of general analysis, as a first step, those present in the research literature on the notion of communication, its importance and the strategy in a company (regardless of the form of organization or area of activity), as well as the factors of influence and those influenced by a good/poor communication. Subsequently, we analysed the information on the agricultural field, the units in this sector, as well as how they work and manage their communication strategy internally and externally, taking into account the modernizations and changes that occur along with the digitization processes.

In order to determine the veracity of the hypotheses from which we started this analysis, we used a quantitative method, a questionnaire that was distributed and filled in by 996 people.

\subsection{Research hypotheses}

Hypothesis no. 1: Within the agricultural units in Romania, regardless of their form of ownership, an organizational communication strategy is not defined at internal and/or external level, the communication process taking place based on intuition.

Hypothesis no. 2: Both internally and externally, the process of organizational communication takes place according to long-standing rules, which are not adapted and correlated with the progress that takes place, including in the field of communication, in the digital age.

Hypothesis no. 3: The lack of measures of alignment with the progress generated by digitalization regarding intra and extra organizational communication results in a great damage caused to the image, but also to the results created by the agricultural units in Romania.

Analysis undertaken on the basis of a questionnaire (placed in crowdsourcing mode on http://www.isondaje.ro/sondaj/793392615/) included a series of questions, both general and practical - applicable to the communication process at the organizational level. Depending on the position held within the organizations, $17.9 \%$ of the respondents are part of the hierarchical management levels, and $82.1 \%$ are part of the execution staff; in terms of gender distribution, the minority proportion is held by men with a percentage of $43.3 \%$, while $56.7 \%$ of respondents are women.

From the point of view of the form of ownership of the organization to which they belong, 
most of the respondents are part of agricultural institutions with state-owned, mixed or foreign equity, as it can be seen in figure no. 1.

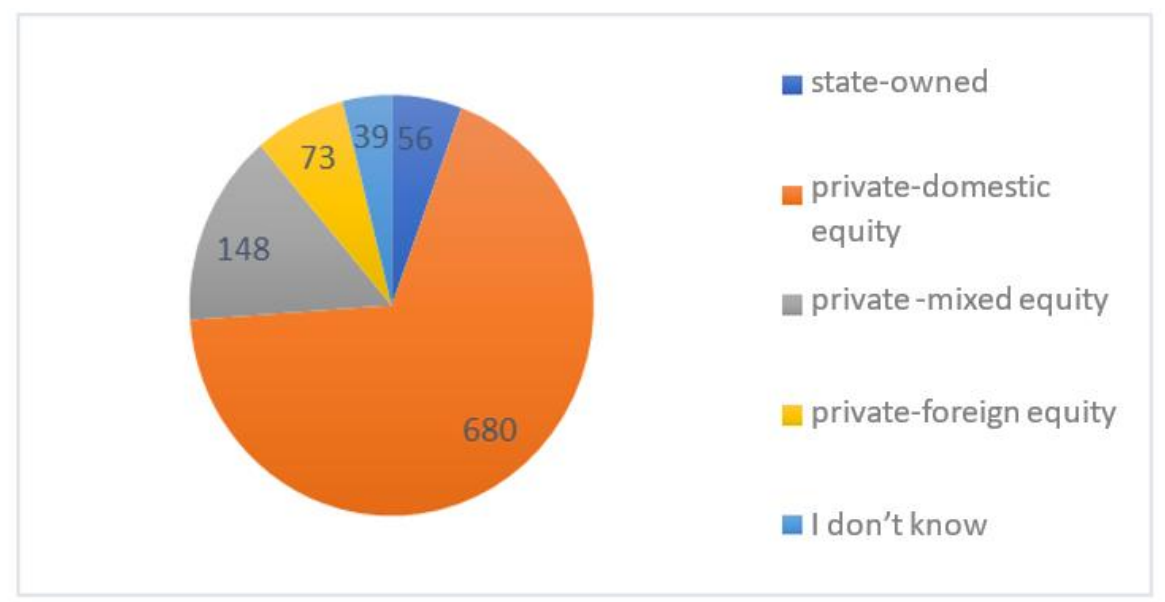

Fig.no.1: Distribution of study participants according to the "ownership of the agricultural unit" criterion Source: processing of responses performed by the author

Another aspect analysed in the first part of the questionnaire is the level of education that the participants have. In figure no. 2 their distribution can be observed, most of them being included at the level of high school or college education.

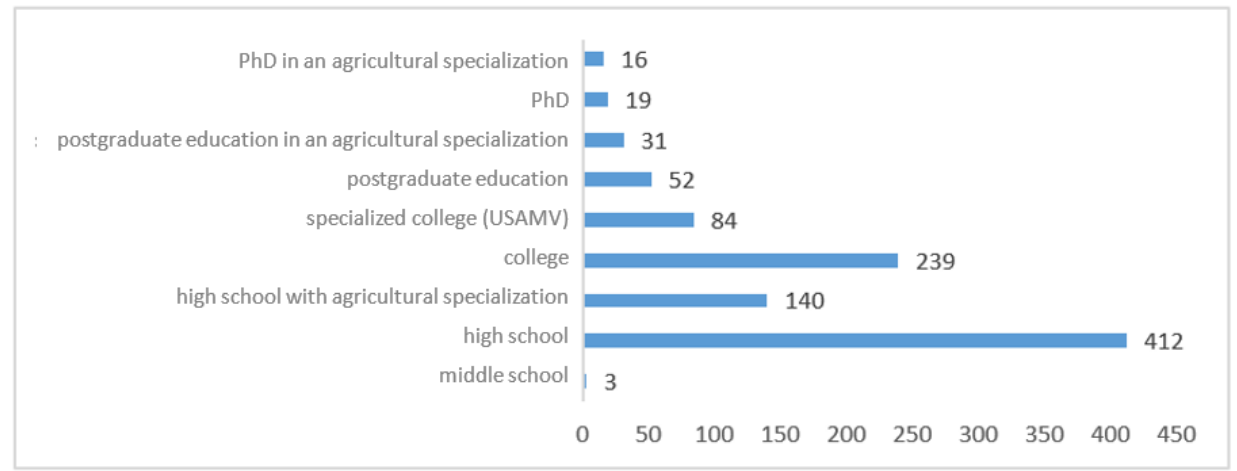

Fig.no.2: Distribution of study participants according to the "level of education" criterion

Source: processing of responses by the author

To create the context of the analysis and to test the working hypotheses, we analysed whether it exists, within the agricultural units, a department specialized in communication, but also the importance assigned to it. For this, the questions that help us draw the first conclusions are detailed below.

To the question "if there is a department dedicated to communication, how many people does it include", most people responded negatively in relation to the existence of such a department. 


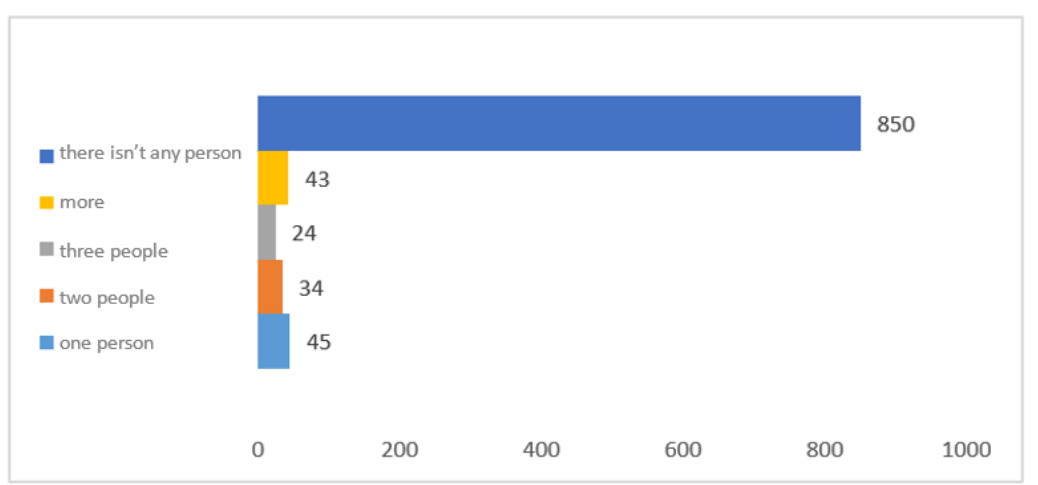

Fig.no.3: Distribution of study participants according to the "organization of Communication Department 1" criterion Source: processing of responses performed by the author

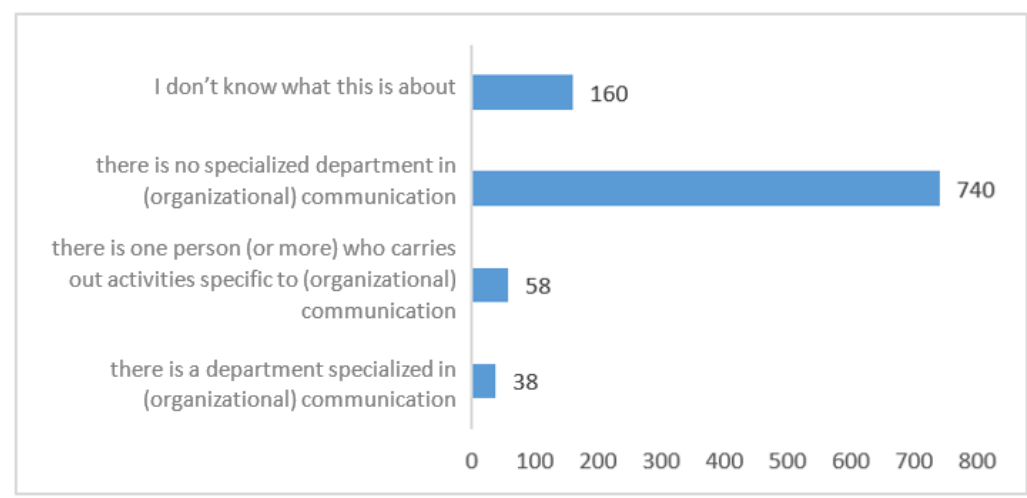

Fig.no.4: Distribution of study participants according to the "organization of Communication Department 2" criterion Source: processing of responses is performed by the author

We find that most respondents are part of agricultural units that do not have a special department dedicated to communication. For an overview, the following two questions aim to show the importance that the management of the units assigns to Communication at intra and extra-organizational level.

The first question refers to the existence, at unit level, of an organizational communication policy; the second question refers to the existence of an organizational communication strategy.

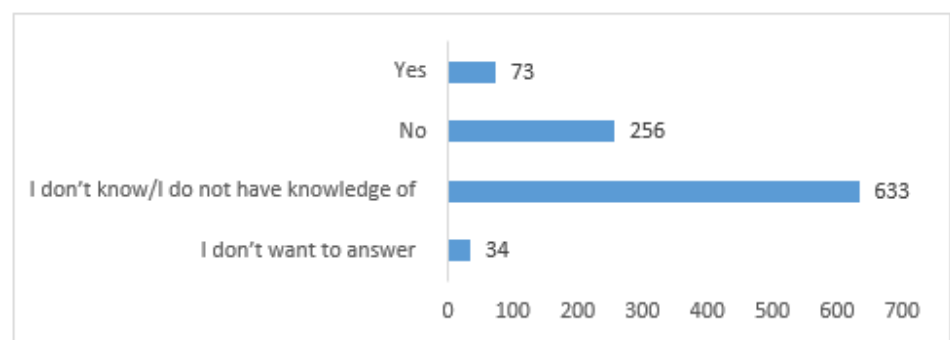

Fig.no.5: Distribution of study participants according to the criterion "organization of Communication Department 3 " 
Source: processing of responses is performed by the author

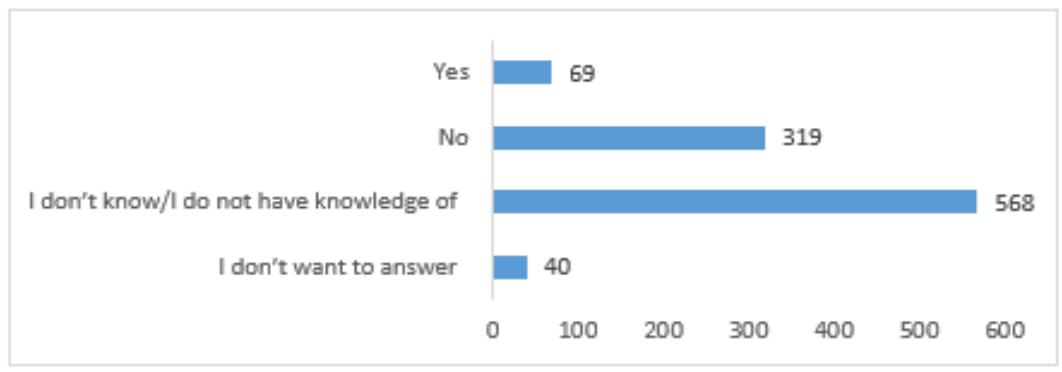

Fig.no.6: Distribution of study participants according to the "organization of Communication Department 4" criterion Source: processing of responses is performed by the author

It can be seen that most respondents do not know whether or not there is a policy or an organizational communication strategy in their unit, respectively, the next answer they chose is the negative one, as in fact, within the units there is no organizational communication policy or strategy. These answers reveal two negative aspects of the functioning of the units: firstly, employees are not informed about how communication takes place, both internally and externally, therefore there are major deficiencies in communication between hierarchical levels, but also between the different departments. Secondly, in units where employees are aware of the situation, most cases indicate a lack of communication policy and strategy, therefore agricultural units do not pay attention to communication, placing it in the background, although this is extremely important, as it is one of the determining factors in relation to the image they have in the external environment.

\subsection{Hypothesis testing}

Hypothesis no. 1: Within the agricultural units in Romania, no communication strategy is defined, regardless of their form of ownership, at internal and/or external level, the communication process taking place based on intuition.

For testing the working hypothesis no. 1, we used the quantitative method of data analysis, using contingency tables. The answers for the 2 questions presented above were analysed, respectively:

"Is there an organizational communication policy in the agricultural unit where you work?"

"Is there an organizational communication strategy in the agricultural unit where you work?"

The independent variable of the analysis we performed is "the form of ownership of the agricultural unit'.

The working hypotheses were the following:

Null hypothesis (HO): there are no differences between the response options selected by the study participants.

Alternative hypothesis (H1): there are significant differences between the response options selected by the study participants; at least one of the response options is preferred by the study participants.

The questions were accessed by all respondents (tab.nr.3.1), there were no situations of missing answers. 
Table no. 1: Case Processing Summary

\begin{tabular}{|c|c|c|c|c|c|c|}
\hline & \multicolumn{6}{|c|}{ Cases } \\
\hline & \multicolumn{2}{|c|}{ Valid } & \multicolumn{2}{|c|}{ Missing } & \multicolumn{2}{|c|}{ Total } \\
\hline & $\mathrm{N}$ & $\%$ & $\mathrm{~N}$ & $\%$ & $\mathrm{~N}$ & $\%$ \\
\hline $\begin{array}{l}\text { Is there an organizational communication policy in the agricultural unit } \\
\text { where you work? } \\
\text { The form of ownership of the agricultural unit in which you carry out your } \\
\text { activity }\end{array}$ & 996 & 100.0 & 0 & 0.0 & 996 & 100.0 \\
\hline $\begin{array}{l}\text { Is there an organizational communication strategy in the agricultural unit } \\
\text { where you work? } \\
\text { The form of ownership of the agricultural unit in which you carry out your } \\
\text { activity }\end{array}$ & 996 & 100.0 & 0 & 0.0 & 996 & 100.0 \\
\hline
\end{tabular}

Source: Processing of the answers from the questionnaire in the IBM SPSS Statistics application is performed by the author of the paper

The answers summarized in table no. 1 are grouped according to the form of ownership of the agricultural unit in which the respondents carry out their activity and indicated that only 73 of them (respectively, $7.32 \%$ of the total) confirm the existence of an organizational communication policy in the agricultural unit in which they operate.

We also find a category with an appreciable share (256 respondents, representing $25.7 \%$ of participants in the study) of people who say that in the agricultural unit where they operate there was no organizational communication policy at the time of the study. Of these, most are employees of private agricultural units with domestic equity (171 respondents, namely $25.15 \%$ of the total).

The representative category is formed of the respondents who state that they do not know or do not have knowledge of the existence of an organizational communication policy in the agricultural unit in which they operate (633 respondents, representing $63.55 \%$ of the total). The important share is held, in this case, by the respondents from private agricultural units, with domestic equity (473 respondents, respectively, $69.56 \%$ of the total participants in the research).

The value of the Pearson contingency coefficient $\chi^{2}$ indicated that there is a significant difference between the response options selected by the study participants, for a significance threshold of the Pearson contingency coefficient $=0.000(<0.05)-$ table no.3.2 -

\section{Table no.2: Crosstab}

\section{Count}

\begin{tabular}{|c|c|c|c|c|c|c|c|}
\hline & \multicolumn{5}{|c|}{$\begin{array}{l}\text { The form of ownership of the agricultural unit } \\
\text { in which you carry out your activity }\end{array}$} & \multirow[b]{2}{*}{ Total } \\
\hline & & $\begin{array}{l}\text { State- } \\
\text { owned }\end{array}$ & $\begin{array}{c}\text { Private, } \\
\text { domestic } \\
\text { equity }\end{array}$ & $\begin{array}{c}\text { Private, } \\
\text { mixed } \\
\text { equity }\end{array}$ & $\begin{array}{l}\text { Private, } \\
\text { foreign } \\
\text { equity }\end{array}$ & $\begin{array}{l}\text { I don't } \\
\text { know }\end{array}$ & \\
\hline \multirow{4}{*}{$\begin{array}{c}\text { Is there an } \\
\text { organizational } \\
\text { communication policy in } \\
\text { the agricultural unit } \\
\text { where you work? }\end{array}$} & Yes & 12 & 29 & 9 & 11 & 12 & 73 \\
\hline & No & 22 & 171 & 36 & 17 & 10 & 256 \\
\hline & $\begin{array}{l}\text { I don't know/I don't } \\
\text { bave knowledge of it }\end{array}$ & 18 & 473 & 88 & 38 & 16 & 633 \\
\hline & I don't want to answer & 4 & 7 & 15 & 7 & 1 & 34 \\
\hline
\end{tabular}




\begin{tabular}{|c|c|c|c|c|c|c|}
\hline Total & 56 & 680 & 148 & 73 & 39 & 996 \\
\hline \multicolumn{7}{|l|}{ Chi-Square Tests } \\
\hline & Value & $\mathrm{df}$ & \multicolumn{4}{|c|}{ Asymp. Sig. (2-sided) } \\
\hline Pearson Chi-Square & $122.800^{\mathrm{a}}$ & 12 & \multicolumn{4}{|c|}{.000} \\
\hline Likelihood Ratio & 100.710 & 12 & \multicolumn{4}{|c|}{.000} \\
\hline Linear-by-Linear Association & 2.574 & 1 & \multicolumn{4}{|c|}{.109} \\
\hline $\mathrm{N}$ of Valid Cases & 996 & & & & & \\
\hline
\end{tabular}

a. 5 cells $(25.0 \%)$ have expected count less than 5 . The minimum expected count is 1.33

Source: Processing of the answers from the questionnaire in the IBM SPSS Statistics application is performed by the author of the paper

The answers summarized in table no. 2, grouped according to the form of ownership of the agricultural unit in which the respondents carry out their activity, follow the same trend as in the previous case. Thus, only 69 respondents (respectively, 6.92\% of the total participants in the study) confirm the existence of an organizational communication strategy in the agricultural unit in which they operate.

An important category is represented, in this case, by the respondents who declare that, in the agricultural unit where they operate, there was no organizational communication strategy at the time of the research (319 respondents, representing 32\% of the study participants). It is worth mentioning that among them, most of them are employees of private agricultural units, with domestic equity (194 respondents).

The representative category is formed by respondents who state that they do not know and/or do not have knowledge of the existence of an organizational communication strategy in the agricultural unit in which they operate (568 respondents, representing $57.02 \%$ of the total). Also, the important share is held by the respondents from private agricultural units, with domestic equity (453 respondents, representing $66.62 \%$ of the total).

The value of the Pearson contingency coefficient $\chi 2$ indicated, also in this case, that there is a significant difference between the response options selected by the respondents, for a significance threshold $=0.000(<0.05)$.

Table no.3: Crosstab

Count

\begin{tabular}{|c|c|c|c|c|c|c|c|}
\hline & \multicolumn{5}{|c|}{$\begin{array}{c}\text { The form of ownership of the } \\
\text { agricultural unit in which you carry out } \\
\text { your activity }\end{array}$} & \multirow[b]{2}{*}{ Total } \\
\hline & & $\begin{array}{l}\text { State- } \\
\text { owned }\end{array}$ & $\begin{array}{l}\text { Private, } \\
\text { domestic } \\
\text { equity }\end{array}$ & $\begin{array}{c}\text { Private, } \\
\text { mixed } \\
\text { equity }\end{array}$ & \begin{tabular}{|c|} 
Private, \\
foreign \\
equity
\end{tabular} & \begin{tabular}{|c|} 
I \\
don't \\
know \\
\end{tabular} & \\
\hline \multirow{4}{*}{$\begin{array}{c}\text { Is there an organizational } \\
\text { communication strategy in the } \\
\text { agricultural unit where you } \\
\text { work? }\end{array}$} & Yes & 12 & 27 & 8 & 11 & 11 & 69 \\
\hline & No & 19 & 194 & 66 & 31 & 9 & 319 \\
\hline & $\begin{array}{l}\text { I don't know/I don't } \\
\text { have knowledge of it }\end{array}$ & 18 & 453 & 59 & 19 & 19 & 568 \\
\hline & I don't want to answer & 7 & 6 & 15 & 12 & 0 & 40 \\
\hline \multicolumn{2}{|l|}{ Total } & 56 & 680 & 148 & 73 & 39 & 996 \\
\hline
\end{tabular}


Chi-Square Tests

\begin{tabular}{|c|c|c|c|}
\hline & Value & $\mathrm{df}$ & Asymp. Sig. (2-sided) \\
\hline Pearson Chi-Square & $179.508^{\mathrm{a}}$ & 12 & .000 \\
\hline Likelihood Ratio & 155.083 & 12 & .000 \\
\hline Linear-by-Linear Association & 9.873 & 1 & .002 \\
\hline N of Valid Cases & 996 & & \\
\hline
\end{tabular}

a. 5 cells $(25.0 \%)$ have expected count less than 5 . The minimum expected count is 1.57

Source: Processing of the answers from the questionnaire in the IBM SPSS Statistics application is performed by the author of the paper

The results of the statistical test performed in order to check the first secondary research bypothesis (SH1) led us to the conclusion that there are significant differences between the response options selected by respondents for each of the variables analysed. As a result, we accepted the first bypothesis of the research, according to which the agricultural units in Romania, regardless of their form of ownership, do not have a defined communication strategy at internal and / or external level, the communication process taking place based on intuition.

Hypothesis no. 2: Both internally and externally, the communication process takes place according to long-standing rules, which are not adapted and correlated with the progress that takes place, including in the field of communication, in the digital era.

To test the second secondary hypothesis, we processed the answers received to the question:

"Please specify the methods used in the external communication process and how you appreciate their efficiency, according to the following grid. Choose all applicable response options".

Respondents had the opportunity to select, from a predefined list the frequently used communication channels, respectively: Website; Email; Newsletter; Social networks; Phone; Videophone; Forum; Blog; Voiceover Internet Protocol; Media advertisements; Social events; Specialized conferences and /or symposiums; Agricultural fairs and exhibitions; Opinion poll and Other communication channels.

The independent variable of the analysis we performed is the "position" held in the organizational structure of the agricultural unit to which one belongs.

For testing hypothesis no. 2, we used the method of comparing the averages, the data being grouped according to the independent variable "position" held by the respondents in the organizational structure.

The working hypotheses were as follows:

Null hypothesis (HO): there are no differences between the response options selected by the study participants.

Alternative hypothesis (H1): there are significant differences between the response options selected by the study participants, at least one of the response options being preferred by the study participants. The questions were accessed by all respondents (table no. 4), with no missing answers.

Table no.4: Case Processing Summary 


\begin{tabular}{|c|c|c|c|c|c|c|}
\hline \multirow{3}{*}{ External communication channel * Position held: } & \multicolumn{6}{|c|}{ Cases } \\
\hline & \multicolumn{2}{|c|}{ Included } & \multicolumn{2}{|c|}{ Excluded } & \multicolumn{2}{|c|}{ Total } \\
\hline & $\mathrm{N}$ & Percent & $\mathrm{N}$ & Percent & $\mathrm{N}$ & Percent \\
\hline Webpage * & 996 & 100.0 & 0 & 0.0 & 996 & 100.0 \\
\hline Email* & 996 & 100.0 & 0 & 0.0 & 996 & 100.0 \\
\hline Newsletter * & 996 & 100.0 & 0 & 0.0 & 996 & 100.0 \\
\hline Social networks * & 996 & 100.0 & 0 & 0.0 & 996 & 100.0 \\
\hline Phone * & 996 & 100.0 & 0 & 0.0 & 996 & 100.0 \\
\hline Videophone * & 996 & 100.0 & 0 & 0.0 & 996 & 100.0 \\
\hline Forum * & 996 & 100.0 & 0 & 0.0 & 996 & 100.0 \\
\hline$B \log *$ & 996 & 100.0 & 0 & 0.0 & 996 & 100.0 \\
\hline Voice over Internet Protocol * & 996 & 100.0 & 0 & 0.0 & 996 & 100.0 \\
\hline Media advertisements * & 996 & 100.0 & 0 & 0.0 & 996 & 100.0 \\
\hline Social events * & 996 & 100.0 & 0 & 0.0 & 996 & 100.0 \\
\hline Specialized conferences and / or symposia * & 996 & 100.0 & 0 & 0.0 & 996 & 100.0 \\
\hline Agricultural fairs and exhibitions * & 996 & 100.0 & 0 & 0.0 & 996 & 100.0 \\
\hline Opinion poll* $*$ & 996 & 100.0 & 0 & 0.0 & 996 & 100.0 \\
\hline Other channels * & 996 & 100.0 & 0 & 0.0 & 996 & 100.0 \\
\hline
\end{tabular}

Source: Processing of the answers from the questionnaire in the IBM SPSS Statistics application is performed by the author of the paper

The results presented in table no. 4 point out that the average response score is lower than the average (3) for responses aimed at the predominant use of traditional communication channels, regardless of the position held by respondents in the organizational structure. This score is calculated for affirmative responses aimed at the low, moderate, or high frequency use of a communication channel.

The analysis of the data from table no. 5 revealed the fact that the most used communication channel remains the phone, for which an average score of 2.85 was registered. The website (with an average score $=2.81$ ), social networks (average score $=2.79$ ) and $e$-mail (average score $=2.77$ ) are also used by both respondents who hold leadership positions and those who with executive roles.

At the opposite pole we have the responses with an average score higher than (4), in which we can include the modern (digital) channels of internal and external communication. These high scores are calculated for affirmative answers in categories "Not applicable", "I don't know / I don't have knowledge of, "or" I don't want to answer / I prefer not to answer)". Thus, the least used to... not at all used communication channels are: Voice over Internet Protocol (average score = 4.55), Media advertisements (average score = 4.53), Agricultural fairs and exhibitions and Opinion poll (each with an average score $=4.50$ ), Specialized conferences and / or symposia (average score $=4.47$ ), Social events (average score $=4.35$ ), Blog (average score $=4.18$ ), Forum (average score $=4.17)$, Videophone (average score $=4.06)$ and Newsletter (average score $=4.01)$. Other communication channels than those mentioned in the questionnaire are much less frequently used (average score $=4.58$ ).

All information regarding the average scores of the use of these communication channels are provided by means of the data from table no. 5 : 
Table no. 5: Report

\begin{tabular}{|c|c|c|c|c|c|c|c|c|c|}
\hline \multirow{3}{*}{ External communication channel: } & \multicolumn{9}{|c|}{ Position held } \\
\hline & \multicolumn{3}{|c|}{ Management } & \multicolumn{3}{|c|}{ Execution } & \multicolumn{3}{|c|}{ Total } \\
\hline & Mean & $\mathrm{N}$ & $\begin{array}{c}\% \text { of } \\
\text { Total N }\end{array}$ & Mean & $\mathrm{N}$ & $\begin{array}{c}\% \text { of } \\
\text { Total } \mathrm{N}\end{array}$ & Mean & $\mathrm{N}$ & $\begin{array}{c}\% \text { of } \\
\text { Total N }\end{array}$ \\
\hline Web page & 2.97 & 178 & 17.9 & 2.77 & 818 & 82.1 & 2.81 & 996 & 100.0 \\
\hline Email & 2.85 & 178 & 17.9 & 2.75 & 818 & 82.1 & 2.77 & 996 & 100.0 \\
\hline Newsletter & 3.69 & 178 & 17.9 & 4.08 & 818 & 82.1 & 4.01 & 996 & 100.0 \\
\hline Social networks & 2.76 & 178 & 17.9 & 2.79 & 818 & 82.1 & 2.79 & 996 & 100.0 \\
\hline Phone & 2.86 & 178 & 17.9 & 2.85 & 818 & 82.1 & 2.85 & 996 & 100.0 \\
\hline Videophone & 3.62 & 178 & 17.9 & 4.15 & 818 & 82.1 & 4.06 & 996 & 100.0 \\
\hline Forum & 3.75 & 178 & 17.9 & 4.26 & 818 & 82.1 & 4.17 & 996 & 100.0 \\
\hline Blog & 3.77 & 178 & 17.9 & 4.27 & 818 & 82.1 & 4.18 & 996 & 100.0 \\
\hline Voice over Internet Protocol & 4.08 & 178 & 17.9 & 4.66 & 818 & 82.1 & 4.55 & 996 & 100.0 \\
\hline Media advertisements & 4.13 & 178 & 17.9 & 4.61 & 818 & 82.1 & 4.53 & 996 & 100.0 \\
\hline Social events & 3.79 & 178 & 17.9 & 4.47 & 818 & 82.1 & 4.35 & 996 & 100.0 \\
\hline Specialized conferences / symposia & 3.96 & 178 & 17.9 & 4.59 & 818 & 82.1 & 4.47 & 996 & 100.0 \\
\hline Agricultural fairs and exbibitions & 4.07 & 178 & 17.9 & 4.59 & 818 & 82.1 & 4.50 & 996 & 100.0 \\
\hline Opinion poll & 4.08 & 178 & 17.9 & 4.59 & 818 & 82.1 & 4.50 & 996 & 100.0 \\
\hline Other channels & 4.19 & 178 & 17.9 & 4.67 & 818 & 82.1 & 4.58 & 996 & 100.0 \\
\hline
\end{tabular}

Source: Processing of the answers from the questionnaire in the IBM SPSS Statistics application is performed by the author of the paper

The results of the statistical test carried out in order to check the second secondary bypothesis of the research led us to the conclusion that there are significant differences between the response options selected by the respondents, for each of the variables analysed. Therefore, we agreed to the validation of the research bypothesis according to which the communication process, both internally and externally, is carried out according to long-standing rules, which are not adapted and correlated with the progress that takes place, including in the field of communication, in the digital age.

Hypothesis no. 3: The lack of measures of alignment with the progress generated by digitalization regarding intra and extra organizational communication results in a great damage caused to the image, but also to the results created by the agricultural units in Romania.

For testing hypothesis no. 3, we drafted two questions aimed at evaluating the activity from the perspective of organizational communication. Subsequently, we processed the answers so that we could complete the picture on the organizational communication in the agricultural units.

"Are organizational communication audits carried out within your organization?"

"Please indicate, if applicable, what aspects of organizational communication are evaluated"

For testing we used the method of frequency of occurrence of responses. The independent variable of the analysis is the "form of ownership" of the agricultural unit.

The working hypotheses were as follows:

Null hypothesis (HO): there are no differences between the response options selected by the respondents. Alternative hypothesis (H1): there are significant differences between the response options selected by respondents. 
The questions were accessed by all respondents (table no. 6), there was no missing answer. The frequency of occurrence of the answers presented in table no. 6 indicated to us that, at the date of the study, in most agricultural units no organizational communication audits were carried out or these activities were not known, according to the data presented in fig.no. 7 .

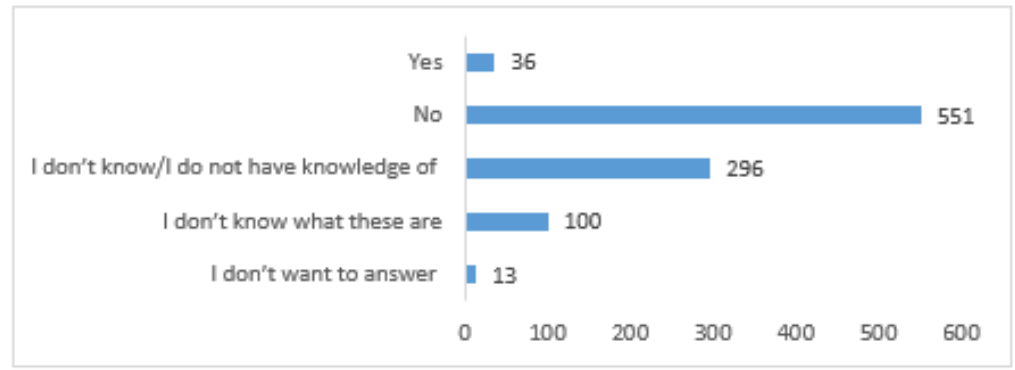

Fig.no.7: Distribution of answers according to the "audit of organizational communication activity" criterion Source: processing of responses performed by the author

Table no. 6: Are organizational communication audits carried out within your organization? * (* Form of ownership of the agricultural unit)

Crosstabulation

\begin{tabular}{|c|c|c|c|c|c|c|c|}
\hline \multirow{2}{*}{\multicolumn{2}{|c|}{ Count }} & \multicolumn{5}{|c|}{$\begin{array}{l}\text { The form of ownership of the agricultural unit in } \\
\text { which you carry out your activity }\end{array}$} & \multirow{2}{*}{ Total } \\
\hline & & State- & Private, & Private, & & Idon't & \\
\hline \multirow{5}{*}{$\begin{array}{c}\text { Are } \\
\text { organizational } \\
\text { communication } \\
\text { audits carried out } \\
\text { within your } \\
\text { organization? }\end{array}$} & Yes & 9 & 9 & 5 & 4 & 9 & 36 \\
\hline & No & 2.3 & 450 & 34 & 25 & 19 & 551 \\
\hline & $\begin{array}{l}\text { I don't know/I don't have } \\
\text { knowledge of this }\end{array}$ & 15 & 182 & 70 & 2.3 & 6 & 296 \\
\hline & I don't know what these are & 6 & 36 & 35 & 19 & 4 & 100 \\
\hline & I don't want to answer & 3 & 3 & 4 & 2 & 1 & 13 \\
\hline \multicolumn{2}{|l|}{ Total } & 56 & 680 & 148 & 73 & 39 & 996 \\
\hline
\end{tabular}

Source: Processing of the answers from the questionnaire in the IBM SPSS Statistics application is performed by the author of the paper

The frequency of occurrence of the responses in Fig. no. 8 follows the same trend of manifestation. Most of the respondents state that, at the time when the study is carried out, there was no audit of the organizational communication activity or they do not know what it is about. Only 171 respondents (17.1\% of the total participants in the research) mention some aspects specific to the audit of the evaluated organizational communication activities.

The image of the organization in relation to third parties is evaluated in 59 agricultural units $(5.5 \%$ of the total entities in which the respondents carry out their activity) - fig.no.8 


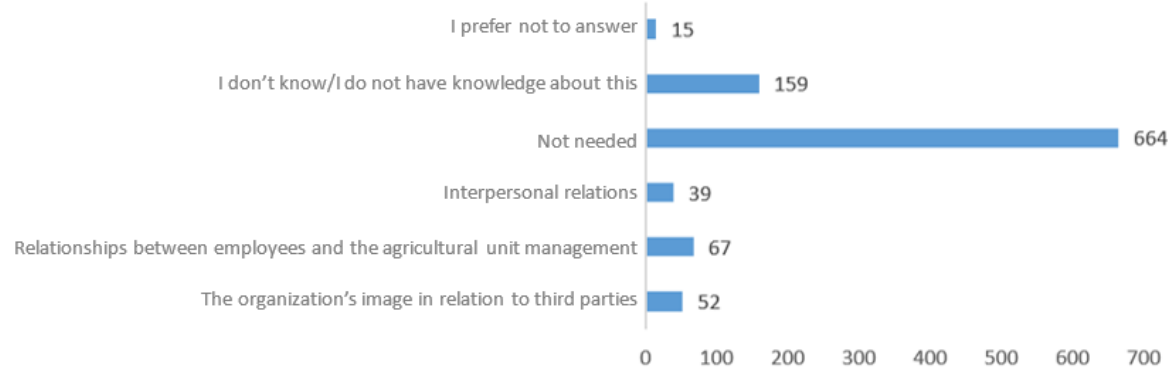

Fig.no.8: Distribution of answers according to the "aspects of the evaluated organizational communication" criterion Source: processing of responses performed by the author

The results of the analysis carried out in order to test the fourth secondary bypothesis of the research bave led us to the conclusion that, in the absence of concrete measures to evaluate the organizational communication activity in agricultural units, it is very difficult to highlight the damage caused to their image and results obtained. Therefore, we accepted the validation of the third bypothesis, according to which the lack of measures of alignment with the progress generated by digitalization regarding intra and extra organizational communication leads to great damage in terms of the image, but also of the results created by agricultural units in Romania.

\section{Conclusions}

Agricultural units in Romania play an extremely important role in the economic development of the country; in fact, agriculture is an extremely important segment of each country's economy. Following the analyses, we noticed that they do not grant a lot of importance to communication, both at intra-organizational level and from the point of view of external communication. At the same time, it is noteworthy that they have not adapted the communication mechanisms to the new trends and changes, which came into being along with the transition to the digital age.

For these reasons and not only, we carried out this analysis, starting with three research hypotheses. Following the testing thereof using econometric means, all of them were validated. All conclusions lead us to the following aspects: the communication process within the agricultural units in the country is carried out based on intuition, as the management does not focus on the development of a communication strategy at internal and external level; moreover, this process works based on long-standing rules, passed on by each generation of employees, without being adapted to the progress that takes place constantly in the field of communication, in the context of the digital age; finally, but not to a lesser degree, this lack of correlation with the progress generated by digitalization determines a negative impact on the image but also on the results produced by the agricultural units in Romania, an impact that often results in direct damage.

Therefore, I consider it imperative that decision-makers in charge of agricultural units understand the role and importance of communication for the efficiency and effectiveness of the carrying out and implementation of activities. According to Mintzberg (1973), in the management activity, interpersonal communication is omnipresent. First, the changes must start from the internal level of each unit, so that each employee understands the flow 
of information, so that the communication process runs smoothly and transparently. Subsequently, a communication policy has to be outlined, simultaneously with a communication strategy, both internally and extra-organizationally. For a company, regardless of the form of ownership and business line, the image it reflects on the outside is vital, because the gaps in communication implicitly reveal shortcomings in intraorganizational communication.

In the context of the digital age, it is extremely important that each entity (in this particular case, each agricultural unit) adapts its internal mechanisms, so that they are correlated with the progress recorded at digital level. Communication and all its mechanisms, as well as organizational policies and strategies, must constantly take into account the changes that occur, the innovations and progress in the economy, so that the organization can easily adapt and maintain its image before all stakeholders.

\section{References}

Abric, J.C. (2002). Psihologia comunicării - Teorii și metode. Iași: Polirom

Boone, K., Meisenbach, T., \& Tucker, M. (2000). Agricultural communications: Changes and challenges, Iowa State University Press

Cole, S., \& Nilesh, A. (2016). 'Mobile'izing Agricultural Advice: Technology Adoption, Diffusion and Sustainability, Harvard Business School, Retrieved April 19, 2021 https://www.hbs.edu/faculty/ Publication\%20Files/13-047_155cb6a2-afb5-4744-a62d-929b01fc9e7c.pdf

Fiske, S. T. (2010). Interpersonal stratification: Status, power, and subordination. Handbook of social psychology, 941-982. Doi: https://doi.org/10.1002/9780470561119.socpsy002026

McNamara, C., (2020). Basics in Internal Organizational Communications. Retrieved April 23, 2021, from https://www.managementhelp.org/organizationalcommunications/internal.htm

Mittal, S. (2016). Role of Mobile Phone-enabled Climate Information Services in Gender-inclusive Agriculture, Gender, Technology and Development, 20(2):200-217, DOI: 10.1177/0971 852416639772

Mintzberg, H. (1973) The Nature of Managerial Work. New York: Harper \& Row

Nicolescu, O., \& Verboncu, I. (2007). Managementul organizației. Bucureşti: Editura Economică

Osgood, C. E. (1953). Method and theory in experimental psychology. Oxford University Press.

Performance of agricultural sector. In Eurostat. Retrieved April 23, 2021, from https://ec.europa.eu/eurostat/web/products-eurostat-news/-/ddn-20210413-2?redirect=\%2F eurostat $\% 2$ Fweb $\% 2$ Fagriculture $\% 2$ Fpublications

Petković, D. et al. (2016). Sensorbes Estimation of Wind Speed by Soft Computing Methodologies: A Comparative Study, Informatics, 26(3):493-508. doi:10.15388/Informatica.2015.60

Popescu, D., \& State, C. (2017). De la ştiința influenţării la arta manipulării. Bucureşti: Editura ASE

Schramm, W. (1971). The Process and Effects of Mass Communication. Urbana: The University of Illinois Press

Shannon, C. E. \& Weaver, W. (1998). The Mathematical Theory of Communication. Urbana: The University of Illinois Press

State, C. (2015). Modalităţi de eficientizare a comunicării organizaţionale în turism. Bucureşti: Academia de Studii Economice

Treise, D., \& Weigold, M.F. (2002). Science Communication, 23(3):310-322. doi:10.1177/1075 54700202300306

Tucker, M., Whaley, S. R. \& Cano, J. (2003). Agricultural Education and Agricultural Communications: striking a proper balance in the Academy. Journal of Agricultural Education, 44(1), 22-30. Doi: http://dx.doi.org/10.5032/jae.2003.01022

Woods, B. (2014). By 2020, 90\% of world's population aged over 6 will have a mobile phone: Report, Retrieved April 20, 2021 from https://thenextweb.com/insider/2014/11/18/2020-90-worlds-populationaged-6-will-mobile-phone-report/

Zlate, M. (2004). Tratat de psihologie organizațional-managerială. Bucureşti: Editura Polirom

Zlate, M. (2004). Treatise on organizational-managerial psychology. Bucharest: Polirom Publishing House 